\title{
Microbiological Analysis of Sachet and Tap Water in Enugu State of Nigeria
}

\author{
Martin E. Ohanu*, Iniekong P. Udoh, Clara I. Eleazar \\ Department of Medical Microbiology, College of Medicine, University of Nigeria, Nsukka, Nigeria \\ Email: "ohanueke@yahoo.com
}

Received August 22, 2012; revised September 27, 2012; accepted November 7, 2012

\begin{abstract}
The microbiological quality of sachet and tap water in Enugu, State, Nigeria was analyzed. Sachet water was purchased from five different manufacturers. Samples $\mathrm{Q}_{1}, \mathrm{~T}_{1}, \mathrm{R}_{1}, \mathrm{~J}_{1}$, and $\mathrm{M}_{1}$ were directly from the manufacturers while samples $Q_{2}, T_{2}, R_{2}, J_{2}$, and $M_{2}$ were obtained from the retailers. Tap water was collected from three different locations in the town. All water samples were subjected to bacteriological (aerobic and anaerobic) and fungal studies using standard bacteriological and mycological methods with little modifications. For sachet water, batch of five packets both from the manufacturer and retailers were analysed and average result taken. Five separate tap water samples were taken from the three different locations. For sachet water, E. coli and S. faecalis were isolated with colony forming units (CFU) ranging from 7 to $>500$. For tap water, isolates included Coliform, Cl. sp and Penicillium sp. An average of $66 \%$ Clostridium sp was recovered from all the tap water of the 3 different locations. Penicillium sp was isolated from only $16.6 \%$ of tap samples. Microbial quality may vary rapidly and widely but short-term peaks in pathogen concentration may increase disease risks considerably and may also trigger outbreaks of waterborne disease.
\end{abstract}

Keywords: Drinking Water; Pathogens; Microbiological Analysis

\section{Introduction}

Water is examined microbiologically to determine its sanitary quality and its suitability for general use. The aim being that it will be acceptable for internal consumption and other uses in contact with man [1]. Water may contain poisonous chemical substances, pathogenic organisms (infective and parasitic agents), industrial or other wastes or sewage and is referred to as being contaminated or polluted. Most of the infections in developing countries can be attributed to lack of safe drinking water (like cholera, typhoid, Hepatitis, Poliomyelitis etc.) [2-4].

Water that is wholesome and fit for drinking is said to be potable [5]. The source of water contamination responsible for the spread of infectious diseases is almost invariably faeces [6,7]. Faecal contamination of water is established by the isolation of an organism that occurs only in faeces, never free-living in nature. There are several such organisms like Echerichia coli, Clostridium perfringens and Streptococcus faecalis. The finding of $E$. coli or Clostridium perfringens and $S$. faecalis is sufficient evidence that the water in question is not safe, since enteric pathogens may be presumed present [8]. The World Health Organization and many other authorities

${ }^{*}$ Corresponding author. continue to support the use of bacterial indicator levels and their isolation as a basis for judging and verifying drinking water quality $[9,10]$. A bacterium can be used as the indicator organism if it fulfils most of the following criteria; present in faeces in abundant number; present in scanty number in other sources; easy to isolate, identify and enumerate, unable to grow in water; able to survive longer in water than other pathogens; more resistant to disinfectants such as chlorine [5]. Estimation of hydrogen sulphide $\left(\mathrm{H}_{2} \mathrm{~S}\right)$ for detection of faecal contamination of drinking water is also in use [11-16].

To determine faecal contamination, the following could be used: presumptive test, confirmed test and completed test [17]. Based on bacteriological tests drinking water is classified as shown in the Table $\mathbf{1}$ below.

Table 1. Guidelines for determination of feacal contamination of water.

\begin{tabular}{cccc}
\hline Class & Grade & $\begin{array}{c}\text { Presumptive count } \\
\text { per } 100 \mathrm{~mL}\end{array}$ & $\begin{array}{c}\text { E. coli count } \\
\text { per } 100 \mathrm{~mL}\end{array}$ \\
\hline I & Excellent & 0 & 0 \\
II & Satisfactory & $1-3$ & 0 \\
III & Suspicious & $4-3$ & 0 \\
IV & Unsatisfactory & 10 & 0,1 , or more \\
\hline
\end{tabular}

Rajesh and Rattan 2004. 
Two methods are commonly used for the detection of indicator bacteria in water; multiple test method and Membrane filter method. An alternative method for the analysis of drinking water by which results can be obtained in 18 hours, based upon defined substrate technology is described by Boubetra [18].

In Nigeria, the National Agency for Food Drug Administration and Control (NAFDAC) checks for the quality of sachet and bottled water among other things, to ensure they are fit for human consumption. Unwholesome water sold to the public is encountered occasionally. They are either coloured or have sediments. The objective of this study is to purchase sachet water from manufacturers, the open market as well as tap water and subject them to microbiological analysis to check for their quality.

\section{Materials and Methods}

Collection of Water Samples: In this study, done in 2008, tap and sachet water were microbiologically analyzed from the manufacturers and retailers. Five bags of water each containing 20 Sachets of water (totaling 100) were purchased from five different manufacturers. Samples $\mathrm{Q}_{1}$, $T_{1}, R_{1}, J_{1}$, and $M_{1}$ were directly from the manufacturers while samples $Q_{2}, T_{2}, R_{2}, J_{2}$ and $M_{2}$ were obtained from the retailers. Tap water from three different areas of Enugu municipality (North (N), West (W) and South (S) were analyzed twice as follows: $\mathrm{N}_{1}, \mathrm{~N}_{2} ; \mathrm{W}_{1}, \mathrm{~W}_{2}$ and $\mathrm{S}_{1}$, $\mathrm{S}_{2}$.

Tap Water Analysis: The outside of the tap was wiped using a clean sterile cloth. The tap was turned on at maximum flow rate and the water allowed to flow for 1 to 2 minutes. The tap was then disinfected for a minute with flame using ignited cotton wool soaked in spirit. The tap was then opened and water was allowed to flow at medium rate for 1 to 2 minutes. A previously sterilized glass container was opened for collecting 2 liter sample of water by holding the bottle steady under the water jet. A small airspace was left in the container to allow for shaking at the time of analysis. The flask was properly stoppered with its cap and brown paper fixed on it with a string [2].

Sachet Water Analysis: A selected edge of the sachet was cleansed with $70 \%$ ethanol, cut open with a sterile scissors and the water poured into a sterile measuring cylinder.

Colony Count: Membrane filters (MF) method. The method described by Noble et al. [19] was strictly followed; $100 \mathrm{mls}$ of each water sample was filtered through sterile membrane which retained the bacteria on its surface. The membrane was removed aseptically and placed on a MacConkey medium that was then incubated at $37^{\circ} \mathrm{C}$ for $24 \mathrm{hrs}$. Coliform colonies (indicating faecal contamination) growing on the surface of the membrane were counted and recorded as Coliform density (total Coliform colonies per $100 \mathrm{~mL}$ ) or colony forming unit (CFU).

Detection of Clostridium perfringens: A modification of the method of Rajesh and Rattan [2] was used. 50 mls each of the water sample was added to $100 \mathrm{~mL}$ of litmus milk in sterile bottles and placed in a water bath at $80^{\circ} \mathrm{C}$ after laying the surface with paraffin to discourage the growth of aerobic bacteria. The bottles were well sealed and incubated at $37^{\circ} \mathrm{C}$ for 5 days. A typical stormy clot reaction together with acidity was regarded as positive for Cl. perfringens. Motility and sulfite reduction tests were carried out for further confirmation as Cl. perfringens is non motile and reduces sulfite to sulfide evidenced by black precipitates of iron sulfide.

Detection of Yeast and Filamentous Fungi: The membrane filter (MF) method was also used. The membrane was removed aseptically and placed on a Sabouraud Dextrose Agar (SDA) and also on Sabouraud Dextose Agar containing $50 \mathrm{mg}$ of Chloramphenicol per litre. These were incubated for 1 - 3 weeks. The presence of yeast and filamentous fungi were recorded as described by Arvanitidou et al., [20].

\section{Results}

The result of the microbiological analysis of sachet and tap water analysis in Enugu state, Nigeria revealed that both water sources had microbial load signifying contamination. The outcome of sachet water analysis is shown in Table 2. The bacterial isolated included Coliforms, Eschericha coli and Enterococci, Strep faecalis, with mean colony forming units (CFU) ranging from 7$>500$ CFU/100mL. The Coliforms count was as follows: Batch Q, Q 1 and $\mathrm{Q}_{2}$ had $500 \mathrm{CFU} / 100 \mathrm{~mL}$ and 200 CFU/100mL, respectively, $\mathrm{T}_{1}$ and $\mathrm{T}_{2}$ (from batch $\mathrm{T}$ ) had $7 \mathrm{CFU} / 100 \mathrm{~mL}$ and $8 \mathrm{CFU} / 100 \mathrm{~mL}$, respectively. The $\mathrm{R}_{1}$ from batch $\mathrm{R}$ had $57 \mathrm{CFU} / 100 \mathrm{~mL}$ of enterococci and no isolate of Coliforms. However, $\mathrm{M}_{1}$ and $\mathrm{M}_{2}$ from batch $\mathrm{M}$ had $35 \mathrm{CFU} / 100 \mathrm{~mL}$ and $50 \mathrm{CFU} / 100 \mathrm{~mL}$ each. There was no anaerobic isolate in any of the sachet water. In fungal studies, Penicillium sp. were isolated from sachets $\mathrm{Q}_{2}$ (40\%), $\mathrm{R}_{1}(30 \%)$ and $\mathrm{M}_{1}(10 \%)$. Tap water analysis is shown in Table 3. The CFU range from 188 to $>1000$ for the bacterial (coliform) aerobic isolates. Clostridium sp. was recovered under the anaerobic bacterial isolates in $66 \%$ of the tap water samples analyzed while Penicillium sp was isolated from only $16.6 \%$ of tap samples.

\section{Discussion}

Escherichia coli (faecal coliforms), Strep faecalis (faecal streptococci) and sulfite reducing clostridia (Clostridium perfringens) were among the organisms isolated. Escherichia coli outnumbered other Coliforms in all the 
Table 2. Mean result of satchet water microbial analysis.

\begin{tabular}{|c|c|c|c|c|c|c|}
\hline Sachet Water Samples & Samples & E. coli & Coliform & Enterococci & Clostridium sp. & Fungal Isolates \\
\hline \multirow[t]{2}{*}{ Q } & $\mathrm{Q}_{1}$ & $>1000 \mathrm{cfu} / 100 \mathrm{~mL}$ & $>500 \mathrm{cfu} / 100 \mathrm{~mL}$ & - & - & - \\
\hline & $\mathrm{Q}_{2}$ & $>500 \mathrm{cfu} / 100 \mathrm{~mL}$ & Coliform $200 \mathrm{cfu} / 100 \mathrm{~mL}$ & - & - & Penicillium sp. 40 (40.0\%) \\
\hline \multirow[t]{2}{*}{$\mathrm{T}$} & $\mathrm{T}_{1}$ & $12 \mathrm{cfu} / 100 \mathrm{~mL}$ & $7 \mathrm{cfu} / 100 \mathrm{~mL}$ & - & - & \\
\hline & $\mathrm{T}_{2}$ & - & $8 \mathrm{cfu} / 100 \mathrm{~mL}$ & - & - & \\
\hline \multirow[t]{2}{*}{$\mathrm{R}$} & $\mathrm{R}_{1}$ & $>500 \mathrm{cfu} / 100 \mathrm{~mL}$ & & $57 \mathrm{cfu} / 100 \mathrm{~mL}$ & - & \\
\hline & $\mathrm{R}_{2}$ & & $>500 \mathrm{cfu} / 100 \mathrm{~mL}$ & - & - & Penicillium sp. 30 (30\%) \\
\hline \multirow[t]{2}{*}{$\mathrm{J}$} & $\mathrm{J}_{1}$ & - & - & - & - & \\
\hline & $\mathrm{J}_{2}$ & $35 \mathrm{cfu} / 100 \mathrm{~mL}$ & - & - & - & - \\
\hline \multirow[t]{2}{*}{ M } & $\mathrm{M}_{1}$ & $55 \mathrm{cfu} / 100 \mathrm{~mL}$ & $35 \mathrm{cfu} / 100 \mathrm{~mL}$ & - & - & Penicillium sp. 10 (10\%) \\
\hline & $\mathrm{M}_{2}$ & - & $50 \mathrm{cfu} / 100 \mathrm{~mL}$ & Nil & - & \\
\hline
\end{tabular}

$A_{1}, B_{1}, R_{1}, J_{1}$ and $M_{1}=$ Samples from Manufacturers; $A_{2}, B_{2}, R_{2}, J_{2}$ and $M_{2}=$ Samples from Retailers.

Table 3. Mean result of tap water microbial analysis.

\begin{tabular}{|c|c|c|c|c|c|c|}
\hline Tap water & Samples & E. coli & Coliform & Enterococci & Clostridium sp. & Fungal Isolates \\
\hline \multirow[t]{2}{*}{$\mathrm{N}$} & $\mathrm{N}_{1}$ & $>1000 \mathrm{cfu} / 100 \mathrm{~mL}$ & $>1000 \mathrm{cfu} / 100 \mathrm{~mL}$ & - & Clostridium sp. & - \\
\hline & $\mathrm{N}_{2}$ & $>1000 \mathrm{cfu} / 100 \mathrm{~mL}$ & $>500 \mathrm{cfu} / 100 \mathrm{~mL}$ & - & - & - \\
\hline \multirow[t]{2}{*}{$\mathrm{W}$} & $\mathrm{W}_{1}$ & $>500 \mathrm{cfu} / 100 \mathrm{~mL}$ & $>1000 \mathrm{cfu} / 100 \mathrm{~mL}$ & - & Clostridium sp. & - \\
\hline & $\mathrm{W}_{2}$ & $300 \mathrm{cfu} / 100 \mathrm{~mL}$ & $>1000 \mathrm{cfu} / 100 \mathrm{~mL}$ & - & Clostridium sp. & - \\
\hline \multirow[t]{2}{*}{$\mathrm{S}$} & $\mathrm{S}_{1}$ & $300 \mathrm{cfu} / 100 \mathrm{~mL}$ & $200 \mathrm{cfu} / 100 \mathrm{~mL}$ & - & Clostridium sp. & Penicillium sp. \\
\hline & $\mathrm{S}_{2}$ & $200 \mathrm{cfu} / 100 \mathrm{~mL}$ & $188 \mathrm{cfu} / 100 \mathrm{~mL}$ & - & Nil & - \\
\hline
\end{tabular}

${ }_{1} \&{ }_{2}$ signifies $1^{\text {st }} \& 2^{\text {nd }}$ sampling from same source.

samples where coliforms were isolated.

There is evidence of Coliform contamination in all the samples both sachet and tap water. The amount of contamination evidenced as CFU/100mL of water sample ranging from 188 - >1000 in tap water and $7->500$ in sachet water speaks for itself and the possibility of some containing pathogens is real. There was no evidence of any anaerobe in all sachet water samples, though $30 \%$ of the samples contained Penicillium sp. isolates. It is known that some Penicillium sp can produce mycotoxin [21,22]. In tap water $66.6 \%$ of samples yielded anaerobic isolates of $C l$. sp.

Comparison of the present study result with that done in Kebbi state of Nigeria on microbiological analysis of sachet drinking water is not encouraging [23]. Microbial water quality may vary rapidly and widely. Short-term peaks in pathogen concentration may increase disease risks considerably and may also trigger outbreaks of waterborne disease. Results of water quality testing for microbes are not normally available in time to inform management action and prevent the supply of unsafe water. Outbreaks of waterborne disease can affect large numbers of persons, this necessitates priority in developing and applying controls on drinking-water quality to check disease outbreak. Sample points should be marked out from water catchment, down the main pipes to end point user (home). How representative of the target population was the study sample in order to ensure confidence in the reliability of the results across a wider group was considered. Hence we selected different areas of Enugu municipality for this study. Household, non-piped water supplies, such as roof catchments (rain water harvesting), surface waters and water collected from wells or springs common in Enugu, may often be contaminated with pathogens. They require treatment and protected storage to achieve safe water. Household water treatment (HWT) methods include:

- Chemical disinfection.

- Membrane, porous ceramic or composite filters.

- Granular media filters.

- Solar disinfection.

- UV light technologies using lamps.

- Thermal heat technologies.

- Coagulation, precipitation and sedimentation.

- Combination (multi-barrier) treatment approach [24].

Drinking water companies (sachet or bottled) can choose any of the above appropriate combinations for water treatment and the empowered government agency 
on such products must supervise them to maintain high standards. Households ideally should boil and filter water before drinking. Since we have plenty of sunshine in our geographical zone, households can store water in large volume transparent containers for additional solar disinfection (radiation). The importance of potable water is well known. Water is an essential part of almost all food processing operatives, being well used as an ingredient, transportation medium, washing and sanitation amongst other activities.

\section{Acknowledgements}

Our immense gratitude go to the technical staff of the Department of Medical Microbiology University of Nigeria Enugu Campus.

\section{REFERENCES}

[1] N. Okafor, “Aquatic and Waste Microbiology,” Fourth Dimension Publishing Co. Ltd. Enugu, 1985, pp. 107126.

[2] W. A. Volk and M. F. "Wheeler, Basic Microbiology," 4th Edition, J.B. Lippincott Company, Philadelphia, 1980, pp. 252-257.

[3] S. A. Townsend, "The Relationship between Salmonella and Faecal Indicator Bacteria Concentrations in Two Pools in the Australia Wet/Dry Tropics," Journal of Applied Bacteriology, Vol. 2, No. 73, 1992, pp. 182-188.

[4] M. D. Sobsey, "Microbial Detection: Implications for Exposure, Health Effects, and Control,” In: G. F. Craun, Ed, Safety of Water Disinfection: Balancing Chemical and Microbial Risks, Intl Life Sciences Inst Pres, Washington DC, 2001, pp. 11-51.

[5] B. Rajesh and L. Rattan, "Microbiology of Water, Milk and Air,” In: B. Rajesh and L. Rattan, Eds., Essential of Medical Microbiology, Brothers Medical Publishers, 2004, pp. 447-450.

[6] K. S. Manja, R. Sambasiva, K. V. Chandrashekhava, K. J. Nath, S. Dutta, K. Gopal, L. Iyengar, S. S. Dhindsa and S. C. Parija, "Report of Study on $\mathrm{H}_{2} \mathrm{~S}$ Test for Drinking Water,” UNICEF, New Delhi, 2001.

[7] D. Nagaruju and J. C. V. Sastri, "Confirmed Faecal Pollution to Bore Well Waters of Mysore City,” Environmental Geology, Vol. 4, No. 38, 1999, pp. 322-326. doi:10.1007/s002540050429

[8] L. W. Sinton, R. K. Finlay and D. L. Hannah, "Distinguishing Human from Animal Faecal Contamination in Water, A Review," New Zealand Journal of Marine \& Freshwater Research, Vol. 2, No. 32, 1998, pp. 323-348. doi:10.1080/00288330.1998.9516828

[9] D. S. Mark and K. P. Frederic, "Evaluation of the $\mathrm{H}_{2} \mathrm{~S}$ Method for Detection of Faecal Contamination of Drinking Water,” WHO/SDE/WSH/02.08 Geneva, 2002.

[10] P. Kaspar, I. Guillen, D. Revelli, T. Meza, G. Velazquez, L. Mino de Kasper, C. Pozolli, C. Nunez and G. Zoulek, "Evaluation of a Simple Screening Test for the Quality of
Drinking Water Systems," Annals of Tropical Medicine and Parasitology, Vol. 3, No. 43, 1992, pp. 124-127.

[11] WHO, “Water Indicators (Draft Document)," OECD, World Health Organization, Geneva, 2002.

[12] G. Castillo, R. Duarte, Z. Ruiz, M. T. Marucic, B. Honorato, R. Mercado, V. Coloma, V. Lorca, M. T. Martins and B. J. Dutka, "Evaluation of Disinfected and Untreated Drinking Water Supplies in Chile by the $\mathrm{H}_{2} \mathrm{~S}$ Paper Strip Test,” Water Research, Vol. 11, No. 28, 1994, pp. 17651770. doi:10.1016/0043-1354(94)90249-6

[13] B. Genthe and M. Franck, "A Tool for Assessing Microbial Quality in Small Community Water Supplies,” WRC Report Pages to Water Research Commission by Division of Water, Environment and Forestry Technology, CSIR, Stellenbosch, Vol. 33, No. 961/1/99, 1999.

[14] M. Martins, G. Castillo and B. J Dutka, "Evaluation of Drinking Water Treatment Plant Efficiency in Microorganism Removal by the Coliphage, Total Coliform and $\mathrm{H}_{2} \mathrm{~S}$ Paper Strip Test," Water Science and Technology, Vol. 3, No. 35, 1997, pp. 403-407. doi:10.1016/S0273-1223(97)00293-X

[15] C. Venkobachar, D. Kumar, K. Taireja, A. Kumar and I. Iyengar, "Assessment of Bacteriological Quality Using a Modified $\mathrm{H}_{2} \mathrm{~S}$ Strip test,” Aqua (Ottoro), Vol. 6, No. 43, 1994, pp. 311-314.

[16] G. K. Rijal, R. S. Fujioka and C. A. Ziel, "Evaluation of the Hydrogen Sulfide Bacteria Test, a Simple Test to Determine the Hygienic Quality of Drinking Water, Abstracts of the General meeting of the American Society for Microbiology," Poster Presentation (Unpublished), American Society of Microbiology, Washington DC, 2000.

[17] P. Kromoredjo and R. Fujioka, "Evaluating Three Simple Methods to Assess the Microbial Quality of Drinking Water in Indonesia," Environmental technology and Water Quality, Vol. 1, No. 6, 1991, pp. 259-270.

[18] A. Boubetra, C. C. Le Nestour Allaert and M. Feinberg, "Validation of Alternative Methods for the Analysis of Drinking Water and Their Application to Escherichia coli," Applied and Environmental Microbiology, Vol. 10, No. 77, 2011, pp. 3360-3367. doi:10.1128/AEM.00020-11

[19] R. T. Noble, M. K. Leecaster, C. D. McGee, S. B. Weisberg and K. Ritter, "Comparison of Total Feacal Coliform and Enterococcus Response for Ocean Recreational Water Quality Testing,” Water Research, Vol. 37, No. 7, 2003, pp. 1637-1643. doi:10.1016/S0043-1354(02)00496-7

[20] M. Arvanitidou, S. Spaia, A. Velegraki, M. Pazargbou, D. Kanetidis, P. Pangidis, N. Askepidis, C. H. Katsinas, G. Vayonas and V. Katsouyannopoulos, "High Level of Reovery of Fungi from Water and Dialysate in Heamolysis Unit,” Journal of Hospital Infection, Vol. 3, No. 45, 2000, pp. 225-230. doi:10.1053/jhin.2000.0763

[21] M. Y. Sweeny and A. D. Dobson, "Mycotoxin Production by Aspergillus, Fusarium and Penicillin Species,” International Journal of Food Microbiology, Vol. 3, No. 43, 1998, pp. 141-158. doi:10.1016/S0168-1605(98)00112-3

[22] M. J. Sweeny, S. White and A. D. W. Dobson, "My- 
cotoxin in Agriculture and Food," Irish Journal of Agriculture and Food Research, Vol. 2, No. 39, 2000, pp. 235-244.

[23] S. Kalpana A. I. Bagudo and A. A. Aliero "Microbiological Analysis of Sachet Drinking Water Marketed at Two Sites in Aliero, Kebbi State, Nigeria,” Continental
Journal of Microbiology, Vol. 1, No. 5, 2011, pp. 29-36.

[24] WHO, “Guidelines for Drinking-Water Quality (3rd Edition), Incorporating First and Second Addenda, Vol. 1, Recommendations,” World Health Organization, Geneva, 2008. 